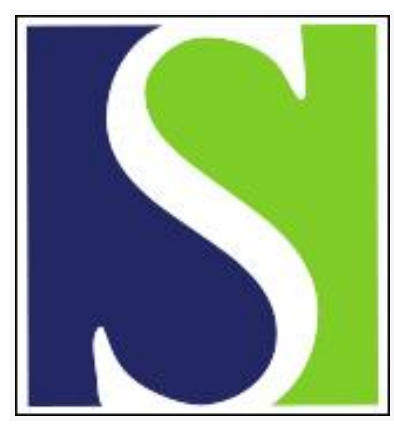

Scand J Work Environ Health 1992;18(5):287-292

https://doi.org/10.5271/sjweh.1575

Issue date: 01 Oct 1992

Oral, pharyngeal and laryngeal cancer as a cause of death among Swiss cooks.

by Foppa I, Minder CE

Affiliation: Department of Medical Statistics, Institute for Social and Preventive Medicine, Berne, Switzerland.

This article in PubMed: www.ncbi.nlm.nih.gov/pubmed/1439654

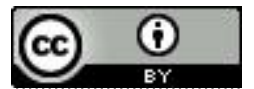




\title{
Oral, pharyngeal and laryngeal cancer as a cause of death among Swiss cooks
}

\author{
by Ivo Foppa, MD, Christoph E Minder, $\mathrm{PhD}^{1}$
}

\begin{abstract}
FOPPA I, MINDER CE. Oral, pharyngeal and laryngeal cancer as a cause of death among Swiss cooks. Scand J Work Environ Health 1992;18:287-92. In an analysis of Swiss mortality data (1979-1987) excess mortality due to oral, pharyngeal and laryngeal cancer was found among cooks, and the rate was very high in the age group $<55$ years. The peak number of cases was observed among cooks in the age category $45-49$ years. In the standard population the highest number of such deaths was observed between 65 and 69 years of age. The numbers of alcohol-related causes of death were also elevated among the cooks, while the numbers of smoking-related deaths were not. Although the dominant role of combined alcohol and tobacco consumption for the development of oral, pharyngeal and laryngeal cancer has been confirmed by many studies, other factors (eg, volatile carcinogenic compounds formed during the cooking process) may contribute to the excess mortality from oral, pharyngeal and laryngeal cancer among cooks. The question of the relevance of such factors will have to be answered by further studies.
\end{abstract}

Key terms: combined alcohol and tobacco consumption, mortality analysis, nominator-denominator bias, pattern of causes of death, volatile carcinogenic compounds.

It is widely accepted that the combined use of alcohol and tobacco is a very important - if not the most important - factor in the etiology of oral, pharyngeal and laryngeal cancer $(1-8)$. Many additional factors have been discussed, like mouthwash use (9), poor dentition (10), dietary deficits (11) and betel nut chewing $(12,13)$, but their contribution to oral, pharyngeal and laryngeal cancer is much less evident. The present study was motivated by the finding of elevated oral, pharyngeal and laryngeal mortality ratios among Swiss cooks (14). Similar findings have been reported from Great Britain (15) and Washington State (16). An elevated risk of oral and pharyngeal cancer, but not of laryngeal cancer, has been found among hotel and restaurant employees in Denmark (17) and among cooks in Italy (18).

\section{Subjects and methods}

\section{Data}

The present study was based on information from the Swiss death registry in 1979-1987 and on 1980 census information, both recorded on magnetic tape. Death certificates of all Swiss men who were older than 29 years and had ever been occupationally active were included in the study, and in this communication they will be referred to as the standard population. Three diagnoses - primary cause of death, immediate cause of death, and concomitant disease - are requested on

1 Department of Medical Statistics, Institute for Social and Preventive Medicine, Berne, Switzerland.

Reprint requests to: Dr I Foppa, Institut für Sozial- und Präventivmedizin, Finkenhubelweg 11,CH-3012 Bern, Switzerland.
Swiss death certificates. These diagnoses are coded by the Federal Bureau of Statistics of Switzerland in terms of the International Classification of Disease, 8th revision (ICD-8) (19). In table 1 only primary causes of death were used for calculating the overall standardizd mortality ratios. Elsewhere, all three diagnoses were included.

Single diagnoses (eg, cancer of the tongue) and groups of diagnoses (eg, oral cancer, oral, pharyngeal and laryngeal cancer) were analyzed. Oral, pharyngeal and laryngeal cancers that are mostly squamous cell carcinomas $(12,20)$ include cancer of the mouth (ICD-8 141, 143-46), pharynx (ICD-8 148-49), and larynx (ICD-8 161), but not cancer of the lips (ICD-8 140), salivary glands (ICD-8 142), or nasopharynx (ICD-8 147), which have different etiologic and pathological features $(12,21)$.

\section{Standardized mortality ratio}

The standardized mortality ratio (SMR) is the ratio of the number of deaths observed to the number expected (22). Expected numbers of deaths were calculated by applying death rates of the standard population to the population of cooks as estimated from the 1980 census. The SMR values were standardized for five-year age categories.

Coding differences for occupation on census forms and death certificates may cause a nominator-denominator bias (22). This kind of bias was reduced by multiplying the expected numbers of deaths with an occupation-specific correction factor based on a sample of 3058 men, deceased in 1981, whose death certificates had been linked to their 1980 census information and compared for occupational information (23). 
Table 1. Corrected standardized mortality ratio (SMR) for all causes and all cancers among Swiss cooks (1979-1987).

\begin{tabular}{|c|c|c|c|c|c|c|}
\hline \multirow{2}{*}{$\begin{array}{l}\text { Age } \\
\text { categories } \\
\text { (years) }\end{array}$} & \multicolumn{3}{|c|}{ All causes } & \multicolumn{3}{|c|}{ Cancera } \\
\hline & $\mathrm{N}$ & SMR & $95 \% \mathrm{Cl}$ & $N$ & SMR & $95 \% \mathrm{Cl}$ \\
\hline $\begin{array}{l}30-34 \\
35-49 \\
40-44 \\
45-49 \\
50-54 \\
55-59 \\
60-64 \\
65-69 \\
70-74 \\
\geq 75\end{array}$ & $\begin{array}{r}39 \\
39 \\
47 \\
37 \\
51 \\
68 \\
89 \\
120 \\
154 \\
289\end{array}$ & $\begin{array}{l}1.71 \\
1.83 \\
2.39 \\
1.66 \\
1.65 \\
1.47 \\
1.33 \\
0.93 \\
1.06 \\
0.95\end{array}$ & $\begin{array}{l}1.10-2.82 \\
1.18-3.02 \\
1.56-3.85 \\
1.06-2.76 \\
1.09-2.64 \\
0.99-2.30 \\
0.90-2.03 \\
0.64-1.40 \\
0.74-1.59 \\
0.67-1.40\end{array}$ & $\begin{array}{r}4 \\
6 \\
10 \\
12 \\
20 \\
18 \\
29 \\
40 \\
54 \\
69\end{array}$ & $\begin{array}{l}1.38 \\
1.54 \\
2.13 \\
1.87 \\
1.91 \\
1.04 \\
1.13 \\
0.85 \\
1.12 \\
0.94\end{array}$ & $\begin{array}{l}0.56-4.58 \\
0.71-4.13 \\
1.11-4.67 \\
1.02-3.88 \\
1.13-3.50 \\
0.61-1.95 \\
0.70-1.93 \\
0.55-1.40 \\
0.74-1.78 \\
0.63-1.50\end{array}$ \\
\hline
\end{tabular}

a International Classification of Diseases, eighth revision, codes 140 209.

Table 2. Corrected standardized mortality ratio (SMR) and proportionate mortality ratio (PMR) values for common types of cancer among Swiss cooks $(1979-1987) .(95 \% \mathrm{Cl}=95 \%$ confidence interval, OPLC $=$ oral, pharyngeal and laryngeal cancer)

\begin{tabular}{|c|c|c|c|c|c|}
\hline Site & $N$ & SMR & $\begin{array}{l}95 \% \mathrm{Cl} \\
\text { of the } \\
\text { SMR }\end{array}$ & PMR & $\begin{array}{c}95 \% \mathrm{Cl} \\
\text { of the } \\
\text { PMR }\end{array}$ \\
\hline
\end{tabular}

Lung (162)

OPLC $(141,143-146$,

148-149, 161)

Prostate gland (185)

Blood and lymphatic

organs $(200-209)$

Liver (155)

Urinary tract $(188,189)$

Stomach (150)

Pancreas (157)

Colon (153)

Rectum (154)

Esophagus (150)

Skin $(172,173)$

Nervous system $(191,192)$

Connective tissue \&

bones $(170,171)$

$\begin{array}{rrrrr}61 & 0.92 & 0.61-1.45 & 0.79 & 0.61-1.02 \\ 36 & 3.03 & 1.93-5.03 & 2.40 & 1.68-3.32 \\ 26 & 0.81 & 0.50-1.42 & 0.81 & 0.53-1.18 \\ & & & & \\ 23 & 1.13 & 0.68-2.01 & 0.95 & 0.60-1.42 \\ 21 & 3.34 & 1.99-6.05 & 2.96 & 1.83-4.52 \\ 17 & 1.02 & 0.59-2.95 & 0.92 & 0.53-1.47 \\ 15 & 0.87 & 0.49-1.71 & 0.79 & 0.44-1.30 \\ 13 & 1.25 & 0.69-2.54 & 1.09 & 0.58-1.87 \\ 13 & 0.73 & 0.40-1.48 & 0.67 & 0.36-1.14 \\ 11 & 1.21 & 0.64-2.57 & 1.09 & 0.55-1.96 \\ 10 & 1.23 & 0.64-2.69 & 1.04 & 0.50-1.92 \\ 6 & 1.10 & 0.46-3.13 & 0.86 & 0.32-1.88 \\ 5 & 0.92 & 0.39-2.65 & 0.63 & 0.20-1.47 \\ & & & & \\ 2 & 1.40 & 0.43-7.84 & 1.07 & 0.13-3.86\end{array}$

a Code of the International Classification of Diseases in parentheses.
Thus overrepresentation of the occupation on death certificates relative to the census forms was corrected for. The correction factor for cooks amounted to 0.763 , leading to corrected SMR values that were about one-fourth lower than the uncorrected ones. There has been no evidence for a considerable age dependency of such correction factors (23). Only corrected SMR values have been used in this paper. The limits of the confidence interval (CI) of the corrected SMR values were calculated according to the following approximate formula (24):

$$
\mathrm{CI}[100(1-\alpha) \%]=[(\mathrm{o} \times \mathrm{c}) / \mathrm{e}] \times \exp \left[\left(\mathrm{u}^{2} / 2\right) \pm \mathrm{z}_{\alpha} \times \mathrm{u}\right],
$$

where $u^{2}=(1 / o)+\left(v / c^{2}\right)+(v / o) \times c^{2}$ and $o=$ observed numbers of deaths, $\mathrm{e}=$ expected numbers of deaths, $c=$ correction factor, and $v=0.0181$ (coefficient of variation).

\section{Proportionate mortality ratio}

Like the SMR, the proportionate mortality ratio (PMR) is a ratio of observed to expected numbers of deaths. In this report, the expected numbers of deaths have been derived from the proportion of a particular cause of death to all deaths in the standard population applied to the number of all deaths among the group of interest (22). Exact Poisson limits were used to calculate the confidence interval for the PMR values.

PMR values are not subject to a numerator-denominator bias because both the observed and expected numbers are drawn from the same data source (death certificates). The discrepancy of relatively low PMR values and corresponding SMR values that were relatively high among the cooks younger than 55 years of age could be attributed to their overall excess mortality (25). Like the SMR values, the PMR values were standardized for five-year age categories. Consideration

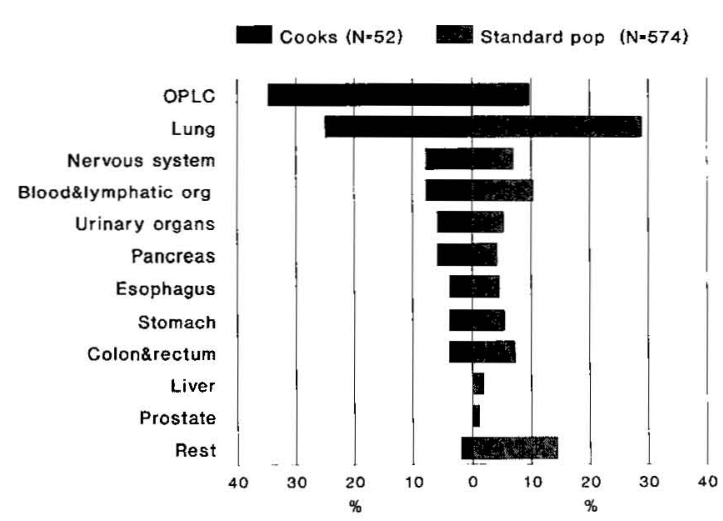

Figure 1. Relative frequency of some common types of cancer compared with that of all cancers on death certificates of 30 - to 54-year-old cooks $(1979-1987)$. (pop $=$ population, OPLC $=$ oral, pharyngeal and laryngeal cancer, org =organs)

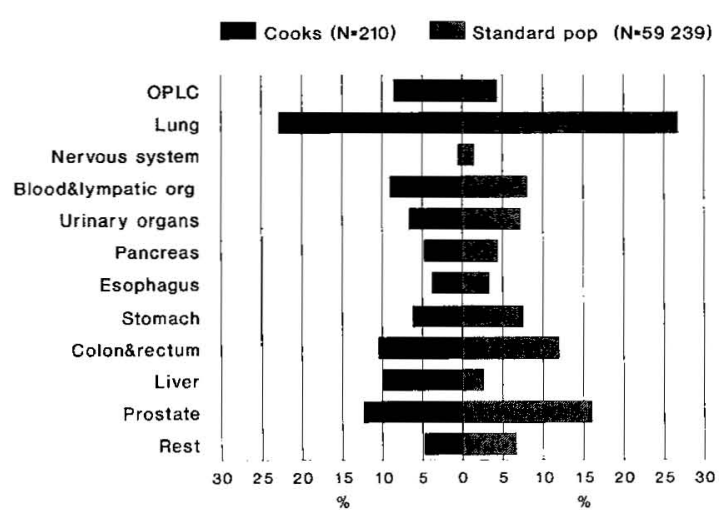

Figure 2. Relative frequency of some common types of cancer compared with all cancers on death certificates of cooks oider than 54 years $(1979-1987)$. $(p o p=$ population, OPLC = oral, pharyngeal and laryngeal cancer, org =organs) 
of both the SMR values and the corresponding PMR values increases the validity of the results.

\section{Results}

\section{Overall and cancer mortality}

The all-cause and all-cancer SMR values of the cooks are presented in table 1 . In the age groups younger than 55 years mortality was elevated not only due to all causes but also due to all cancer. In table 2 the mortality ratios for deaths attributed to some common types of cancer are given. Oral, pharyngeal and laryngeal cancer and cancer of the liver occurred in excess. Mortality due to esophageal cancer - a cancer also considered to be strongly related to combined alcohol and tobacco consumption (26) - and lung cancer mortality were not elevated.

Figures 1 and 2 compare the proportions of some common types of cancer to all cancers among the cooks and the standard population. In the younger age group, $35 \%$ of all cancers among the cooks was oral, pharyngeal or laryngeal cancer, and $25 \%$ was lung cancer, while in the standard population oral, pharyngeal and laryngeal cancer accounted for only $10 \%$ and lung cancer for $29 \%$ (figure 1 ).

In the older age group cancer of the liver was the third most common cancer among the cooks, while in the standard population it ranked only ninth (figure 2).

\section{Mortality from oral, pharyngeal and laryngeal cancer}

Figure 3 represents the observed and expected numbers of deaths due to oral, pharyngeal and laryngeal cancer among the cooks in 10 five-year age categories. The expected numbers corresponded to the denominator of the corrected SMR values. The number of deaths was higher than expected in every age category. The highest number of deaths due to oral, pharyngeal and laryngeal cancer was expected to have occurred between 65 and 69 years of age but was found to have occurred 20 years earlier ( $45-49$ years of age), when seven deaths attributed to oral, pharyngeal and laryngeal cancer contrasted with less than one expected.

Table 3 gives the SMR and PMR values for oral, pharyngeal and laryngeal cancer in two age groups. The SMR values ranged between 6.63 (larynx) and 7.85 (oral cavity) in the younger age group, the corresponding PMR values being lower by a factor of a little less than two. This difference is related to a general excess mortality among the cooks of younger ages. (See the preceding text.) In the older age group the SMR and PMR values were elevated only for laryngeal cancer.

In table 4 the SMR and PMR values are presented for cancer of the tongue, which was the individual diagnosis with the highest excess mortality among the cooks under 55 years of age. The SMR amounted to 10.31 in this age group but was not elevated in the older age group.

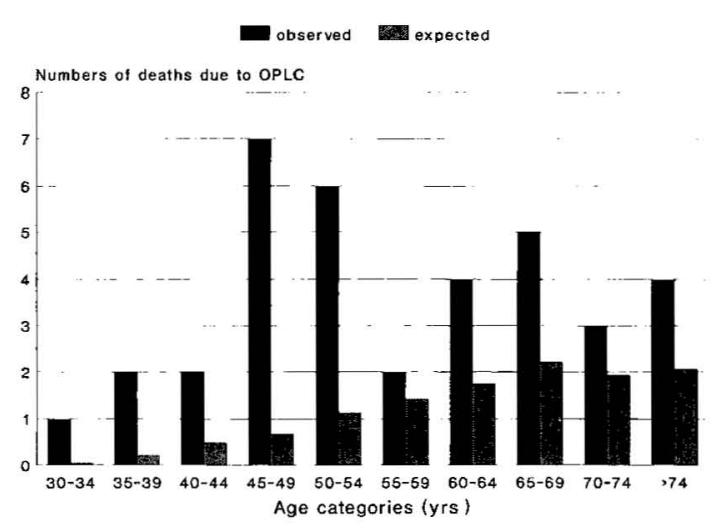

Figure 3. Observed numbers of deaths due to oral, pharyngeal and laryngeal cancer (OPLC) among cooks in 10 age categories contrasted with the expected numbers of deaths (denominator of the corrected standardized mortality ratios) (19791987).

Table 3. Corrected standardized mortality ratio (SMR) and proportionate mortality ratio (PMR) for oral, pharyngeal and laryngeal cancer among the cooks in two age groups (1979-1987). (95\% Cl=95\% confidence interval)

\begin{tabular}{|c|c|c|c|c|c|}
\hline Cancer site ${ }^{a}$ & $\mathrm{~N}$ & SMR & $\begin{array}{c}95 \% \mathrm{Cl} \\
\text { of the SMR }\end{array}$ & PMR & $\begin{array}{c}95 \% \mathrm{Cl} \\
\text { of the PMR }\end{array}$ \\
\hline \multicolumn{6}{|l|}{ Oral cavity $(141-144)$} \\
\hline $\begin{array}{l}\text { Cooks } 30-54 \text { years of age } \\
\text { Cooks }>54 \text { years of age }\end{array}$ & $\begin{array}{l}7 \\
4\end{array}$ & $\begin{array}{l}7.58 \\
1.44\end{array}$ & $\begin{array}{l}3.75-19.65 \\
0.58-4.77\end{array}$ & $\begin{array}{l}4.32 \\
1.29\end{array}$ & $\begin{array}{l}1.74-8.90 \\
0.35-3.29\end{array}$ \\
\hline \multicolumn{6}{|l|}{ Pharynx $(146,148,149)$} \\
\hline $\begin{array}{l}\text { Cooks } 30-54 \text { years of age } \\
\text { Cooks }>54 \text { years of age }\end{array}$ & $\begin{array}{l}7 \\
5\end{array}$ & $\begin{array}{l}6.68 \\
1.49\end{array}$ & $\begin{array}{l}3.19-16.70 \\
0.65-4.36\end{array}$ & $\begin{array}{l}3.80 \\
1.31\end{array}$ & $\begin{array}{l}1.53-7.84 \\
0.43-3.05\end{array}$ \\
\hline \multicolumn{6}{|l|}{ Larynx (161) } \\
\hline $\begin{array}{l}\text { Cooks } 30-54 \text { years of age } \\
\text { Cooks }>54 \text { years of age }\end{array}$ & $\begin{array}{l}4 \\
9\end{array}$ & $\begin{array}{l}6.63 \\
2.79\end{array}$ & $\begin{array}{l}2.67-21.9 \\
1.42-6.34\end{array}$ & $\begin{array}{l}3.67 \\
2.54\end{array}$ & $\begin{array}{l}1.00-9.40 \\
1.16-4.83\end{array}$ \\
\hline
\end{tabular}

a Code of the International Classification of Diseases in parentheses. 


\section{Causes of death associated with smoking and} high alcohol intake

The SMR and PMR values due to smoking- and alcohol-related diseases $(27,28,29)$ among the cooks are presented in table 5. Mainly in the younger age group there was excess mortality due to liver cirrhosis, while only in the older group was mortality elevated due to the somewhat poorly defined condition of "alcoholism or alcoholic psychosis." Smoking-related diseases, on the other hand, did not occur in excess.

\section{Discussion}

The aim of the present study was to analyze the high mortality from oral, pharyngeal and laryngeal cancer among cooks, a phenomenon previously observed but not yet subject to a more profound analysis. Overestimation of the SMR values due to a numeratordenominator bias caused by coding differences on death certificates and census forms was statistically corrected for. A bias arising from an overrepresentation of oral, pharyngeal and laryngeal cancer on the death certificates of cooks is unlikely for an occupation not generally known to be related to this specific cause of death (30). The very high SMR values, the presumable absence of considerable bias, and the close correspondence of the SMR and PMR values (taking into ac-

Table 4. Corrected standardized mortality ratio (SMR) and proportionate mortality ratio (PMR) for cancer of the tongue (International Classification of Diseases, eighth revision, code 141) among the cooks in two age groups in 1979-1987. (95\% $\mathrm{Cl}=95 \%$ confidence interval)

\begin{tabular}{lcrccc}
\hline Age group & N & SMR & $\begin{array}{c}95 \% \text { Cl } \\
\text { of the SMR }\end{array}$ & PMR & $\begin{array}{c}95 \% \mathrm{Cl} \\
\text { of the PMR }\end{array}$ \\
\hline $30-54$ years & 5 & 10.31 & $4.47-30.17$ & 5.62 & $\begin{array}{l}1.82-13.11 \\
>54 \text { years }\end{array}$ \\
\hline
\end{tabular}

count the high general mortality of cooks younger than 55 years of age) are strong arguments for a real effect. Information on the smoking and drinking history of the cooks in comparison with that of the standard population would be very useful for interpreting the results. In a study on work conditions and well-being in Switzerland, kitchen personnel were found to belong to the occupational group with the highest intake of hard liquors but to have a relatively small proportion of current smokers (31). Unfortunately, this information is only of limited use, as we do not know much about the time trend of drinking and smoking behavior among cooks. The pattern of causes of death, on the other hand, does reflect the life-long exposure to occupational and life-style hazards, but it is very difficult to interpret. To overcome this dilemma, a questionnaire inquiry asking for information on the alcohol and tobacco consumption of the cases was conducted in an early phase of the study. Physicians with access to the medical records of the 28 deceased cooks (only oral, pharyngeal and laryngeal cases from 1979 to 1985 ) were contacted. In 15 cases, from the 19 that could be identified by the physicians, information on smoking and drinking history was available. All of these patients had been documented as consuming at least one type of alcoholic beverage several times per day and mostly at least one pack of cigarettes per day. This information is certainly subject to various biases. But in the context of the information presented it seems to be a reasonable and conservative assumption that heavy drinking and smoking was a condition sine qua non for the cooks' excess mortality due to oral, pharyngeal and laryngeal cancer. Nevertheless, the evident age dependency of the mortality ratios for oral, pharyngeal and laryngeal cancer among the cooks, together with some features of their cancer mortality pattern, strongly suggests a substantially different exposure compared with that of the standard population. Even

Table 5. Corrected standardized mortality ratio (SMR) and proportionate mortality ratio (PMR) for smoking-and alcohol-related causes of deaths among Swiss cooks in two age groups (1979-1987).

\begin{tabular}{|c|c|c|c|c|c|}
\hline Diagnosis $^{a}$ & $\mathrm{~N}$ & SMR & $\begin{array}{c}95 \% \mathrm{Cl} \\
\text { of the SMR }\end{array}$ & PMR & $\begin{array}{l}95 \% \mathrm{Cl} \\
\text { of the PMF }\end{array}$ \\
\hline \multicolumn{6}{|l|}{ Liver cirrhosis (571) } \\
\hline $\begin{array}{l}\text { Cooks } 30-54 \text { years of age } \\
\text { Cooks }>54 \text { years of age }\end{array}$ & $\begin{array}{l}30 \\
51\end{array}$ & $\begin{array}{l}4.73 \\
2.54\end{array}$ & $\begin{array}{l}2.96-8.07 \\
1.67-4.07\end{array}$ & $\begin{array}{l}2.59 \\
2.30\end{array}$ & $\begin{array}{l}1.75-3.70 \\
1.72-3.06\end{array}$ \\
\hline \multicolumn{6}{|c|}{ Alcoholism (291), alcoholic psychosis (303) } \\
\hline $\begin{array}{l}\text { Cooks } 30-54 \text { years of age } \\
\text { Cooks }>54 \text { years of age }\end{array}$ & $\begin{array}{l}22 \\
40\end{array}$ & $\begin{array}{l}2.74 \\
2.76\end{array}$ & $\begin{array}{l}0.68-4.93 \\
1.78-4.53\end{array}$ & $\begin{array}{l}1.48 \\
2.49\end{array}$ & $\begin{array}{l}0.93-2.25 \\
1.18-3.39\end{array}$ \\
\hline \multicolumn{6}{|l|}{ Lung cancer (162) } \\
\hline $\begin{array}{l}\text { Cooks } 30-54 \text { years of age } \\
\text { Cooks }>54 \text { years of age }\end{array}$ & $\begin{array}{l}13 \\
48\end{array}$ & $\begin{array}{l}1.76 \\
0.81\end{array}$ & $\begin{array}{l}0.97-3.58 \\
0.53-1.31\end{array}$ & $\begin{array}{l}0.99 \\
0.75\end{array}$ & $\begin{array}{l}0.53-1.69 \\
0.55-1.00\end{array}$ \\
\hline \multicolumn{6}{|c|}{ Bronchitis, emphysema, asthma (490-493) } \\
\hline $\begin{array}{l}\text { Cooks } 30-54 \text { years of age } \\
\text { Cooks }>54 \text { years of age }\end{array}$ & $\begin{array}{r}3 \\
65\end{array}$ & $\begin{array}{l}1.16 \\
1.03\end{array}$ & $\begin{array}{l}0.42-4.68 \\
0.69-1.61\end{array}$ & $\begin{array}{l}0.66 \\
1.00\end{array}$ & $\begin{array}{l}0.14-1.94 \\
0.77-1.27\end{array}$ \\
\hline \multicolumn{6}{|c|}{ Ischemic heart disease $(410-414)$} \\
\hline $\begin{array}{l}\text { Cooks } 30-50 \text { years of age } \\
\text { Cooks }>54 \text { years of age }\end{array}$ & $\begin{array}{r}22 \\
167\end{array}$ & $\begin{array}{l}1.32 \\
0.97\end{array}$ & $\begin{array}{l}0.80-2.38 \\
0.68-1.44\end{array}$ & $\begin{array}{l}0.73 \\
0.93\end{array}$ & $\begin{array}{l}0.46-1.11 \\
0.79-1.08\end{array}$ \\
\hline
\end{tabular}

a Code of the International Classification of Diseases in parentheses. 
though this difference might be purely quantitative, the following statement by Brugere et al (32) seems worth considering: "In particular, for the cancer sites for which all of the patients are smokers, the effect of other risk factors cannot be studied without considering their interaction with tobacco consumption. This kind of information is important for the study of risk factors other than alcohol and tobacco consumption, particularly the study of occupational risk factors [p 395]." Moreover, Doll (33) pointed out that "it is the relatively young who first provide evidence of an occupational hazard of cancer [p 679]." In fact cooks are faced with at least two hypothetical occupational hazards possibly modifying the effects of smoking and drinking. Air samples from different restaurant cooking areas have been found by Teschke et al (34) to be more frequently mutagenic than samples from dining areas. Rappaport et al (35) has suspected that volatile carcinogenic compounds - mainly formed in the cooking process of meat - could constitute an occupational hazard to cooks and kitchen personnel. A second hypothetical occupational hazard is chronic thermal irritation of the upper aerodigestive tract from the frequent tasting of hot food. Thermal injury of the esophageal mucosa caused by hot food and beverages has been suspected as an etiologic factor for esophageal cancer in some high-incidence areas (36). Such areas (like, eg, central Iran) mostly have high incidence rates for oral cancer too (37). The relevance of these two factors will have to be enlightened by further studies.

\section{Acknowledgments}

This investigation was sponsored by the Swiss National Science Foundation (project on mortality by socioeconomic group, no 3.985.0.87). We acknowledge the cooperation of the federal bureau of statistics of Switzerland in giving us access to the mortality data and thank the physicians involved in the inquiry for their cooperation.

\section{References}

1. Adelhardt M, Moller Jensen O, Sand Hansen H. Cancer of the larynx, pharynx and oesophagus in relation of alcohol and tobacco consumption among Danish brewery workers. Dan Med Bull 1985;32:119-25.

2. Blot WJ, McLaughlin JK Winn DM, Austi DF, Greenberg RS, Preston-Martin S, et al. Smoking and drinking in relation of oral and pharyngeal cancer. Cancer Res 1988;48:3282- 87 .

3. Brownson RC, Chang JC. Exposure to alcohol and tobacco and the risk of laryngeal cancer. Arch Environ Health 1987:42:192-6.

4. De Stefani E, Correa P, Oreggia F, Leiva J, Rivero S, Fernandez G, et al. Risk factors for laryngeal cancer. Cancer 1987;60:3087-91.

5. Olsen J, Sabroe S. Occupational causes of laryngeal cancer. J Epidemiol Community Health 1984;38:117-21.

6. Rothman K, Keller A. The effect of joint exposure to alcohol and tobacco on risk of cancer of the mouth and pharynx. J Chronic Dis 1972;25:711-6.

7. Spitz MR, Fueger JJ, Goepfert H, Hong WK, Newell GR. Squamous cell carcinoma of the upper aerodigestive tract. Cancer 1988;61:203-8.

8. Tuyns AJ, Estève J, Raymond L, Berrino F, Benhamou E, Blanchet F, Boffeta P, et al. Cancer of the larynx/ hypopharynx, tobacco and alcohol: IARC International case-control study in Turin and Varese (Italy), Zaragoza and Navarra (Spain), Geneva (Switzerland) and Calvados (France). Int J Cancer 1988;41:483-91.

9. Mashberg A, Barsa P, Grossman ML. A study of the relationship between mouthwash use and oral and pharyngeal cancer. J Am Dent Assoc 1985;110:731-4.

10. Young TB, Ford CN, Brandenburg JH. An epidemiologic study of oral cancer in a statewide network. Am J Otolaryngol 1986;7:200-8.

11. McLaughlin JK, Gridley G, Block G, Winn DM, Preston-Martin S, Schoenberg JB, et al. Dietary factors in oral and pharyngeal cancer. J Natl Cancer Inst 1988; $80: 1237-43$

12. Mahboubi E, Sayed GM. Oral cavity and pharynx. In: Schottenfeld D, Fraumeni JF, ed. Cancer epidemiology and prevention. Philadelphia, PA: Saunders, 1982: 583-95.

13. Waterhouse J, Muir C, Shanmugaratnam K, Powell J. Cancer incidence in five continents; vol IV. Lyon: International Agency for Research on Cancer, 1982:392. (IARC scientific publications; no 42.)

14. Minder CE, Beer V. Cancer mortality by occupation among Swiss men, 1979-1982. Scand J Work Environ Health. In press.

15. Office of Population Censuses and Surveys. Occupational mortality 1979-80, 1982-83. London: Her Majesty's Stationery Office, 1986:microfiche tables.

16. Milham S Jr. Occupational mortality in Washington state 1950 - 1979. Washington, DC: US Department of Health, Education, and Welfare, 1983.

17. Olsen JH, Jensen OM. Occupation and risk of cancer in Denmark: an analysis of 93810 cancer cases, 19701979. Scand J Work Environ Health 1987;13 suppl $1: 1-91$.

18. Merletti F, Boffena P, Ferro G, Pisani P, Terracini B. Occupation and cancer of the oral cavity or oropharynx in Turin, Italy. Scand J Work Environ Health 1991;17: 248-54.

19. Eidgenössisches Statistisches Amt. Internationale Klassifikation der Krankheiten und Todesursachen. Ergänzt für den Schweizerischen Gebrauch (8.Revision). Bern: Eidgenössisches Statistisches Amt, 1970.

20. Austin DF. Larynx. In: Schottenfeld D, Fraumeni JF, ed. Cancer epidemiology and prevention. Philadelphia, PA: Saunders, 1982:554-63.

21. Shanmugaratnam K. Nasopharynx. In: Schottenfeld D, Fraumeni JF, ed. Cancer epidemiology and prevention. Philadelphia, PA: Saunders, 1982:536-53.

22. Office of Population Censuses and Surveys. Occupational mortality 1979-80, 1982-83. London: Her Majesty's Stationery Office, 1986:19-24.

23. Beer V, Greusing TH, Minder CE. Berusfsbezogene sozio-ükonomische Gruppen für die Schweiz: sozialwissenschaftliche Grundlagen und Untersuchungen zur Validität. Soz Praev Med 1986;31:274-80.

24. Goodman LA. On the exact variance of products. J Am Stat Assoc 1960:55:708-13.

25. Decouflé $P$, Thomas TL, Pickle LW. Comparison of the proportionate mortality ratio and the standardised mortality ratio risk measures. Am J Epidemiol 1980; 111:263-9.

26. Day NE, Muñoz N. Esophagus. In: Schottenfeld D, Fraumeni JF, ed. Cancer epidemiology and prevention. Philadelphia, PA: Saunders, 1982:596-623.

27. Royal College of Physicians of London. Smoking and health now. London: Pitman Medical and Scientific 
Publishing Company, 1971:48-94.

28. Takeshi $\mathbf{H}$. Health effect of active and passive smoking. In: Aoki M, Hisamichi S, Tominaga S, ed. Smoking and health 1987: proceedings of the 6th World Conference on Smoking and Health; 1887 Nov 9-12; Tokio. Amsterdam: Elsevier Science Publishers, 1988:75-86.

29. Grant FG, Dufur MC, Harford TC. Epidemiology of alcoholic liver disease. Semin Liver Dis 1988;8(1):1325.

30. Office of Population Censuses and Surveys. Occupational mortality 1979-80, 1982-83. London: Her Majesty's Stationery Office, 1986:12.

31. Buchberger J, Fahrni M. Arbeitsbedingungen und gesundheitliches Befinden-Beurteilung durch Erwerbstätige in der Schweiz. Bern: Bundesamt für Industrie, Gewerbe und Arbeit, 1990.

32. Brugere J, Guenel P, Leclerc A, Rodriguez J. Differential effects of tobacco and alcohol in cancer of the larynx, pharynx and mouth. Cancer 1986;57:391 - 5.
33. Doll R. Progress against cancer: an epidemiologic assessment. Am J Epidemiol 1991:134:675-90.

34. Teschke K, Hertzman C, Van Netten C, Lee E, Morrison B, Cornista A, et al. Potential exposure of cooks to airborne mutagens and carcinogens. Environ Res 1989;50:296-308.

35. Rappaport SM, McCartney MC, Wei ET. Volatilization of mutagens from beef during cooking. Cancer Lett 1979;8:139-45.

36. Ghadirian P. Thermal irritation and esophageal cancer in northern Iran. Cancer 1987;60:1909-13.

37. Zaridze DG, Blettner M, Trapeznikov NN, Kuvshinov JP, Matiakin EG, Poljakov BP, et al. Survey of a population with a high incidence of oral and esophageal cancer. Int J Cancer 1985;36:153-8.

Received for publication: 18 November 1991 